\title{
Determining the Sources of Primary and Secondary Inoculum and Seasonal Inoculum Dynamics of Fungal Pathogens Causing Fruit Rot of Deciduous Holly
}

\author{
Shan Lin and Francesca Peduto Hand ${ }^{\dagger}$ \\ Department of Plant Pathology, The Ohio State University, Columbus, OH 43210
}

\begin{abstract}
Fruit rot of deciduous holly, caused by species of the genera Alternaria, Colletotrichum, Diaporthe, and Epicoccum, is affecting plant production in Midwestern and Eastern U.S. nurseries. To determine the sources of inoculum, dormant twigs and mummified fruit were collected, and leaf spot development was monitored throughout the season from three Ohio nurseries over two consecutive years. Mummified fruit was the main source of primary inoculum for species of Alternaria and Epicoccum, whereas mummified fruit and bark were equally important for species of Colletotrichum and Diaporthe. Brown, irregular leaf spots developed in

inoculum for fruit infections. In addition, spore traps were used to monitor seasonal inoculum abundance in the nurseries. Fruit rot pathogens were captured by the spore traps throughout the season, with peak dissemination occurring during flowering. In this study, we also attempted to understand the role of environmental factors on leaf spot development. Although leaf spot incidence and severity were negatively correlated to mean maximum, minimum and average temperature, a decrease in temperature also coincided with leaf senescence. The role of temperature on leaf spot development should be further studied to fully interpret these results.
\end{abstract} the summer, and disease incidence and severity increased along with leaf and fruit development. Coalesced leaf spots eventually resulted in early plant defoliation. When tested for their pathogenicity on fruit, leaf spot isolates were able to infect wounded mature fruit and induce rot symptoms, which indicated that leaf spots could serve as a source of secondary
Keywords: Causal agent, climate/weather effects, crop type, cultural and biological practices, disease development and spread, disease management, epidemiology, fungi, ornamentals, pathogen survival, winterberry, woody ornamentals.
Fruit rot of deciduous holly (Ilex spp. L.) was recently reported as an emerging threat to plant production across Midwestern and Eastern U.S. nurseries (Lin et al. 2018). It was determined that multiple fungal pathogens can cause the disease, primarily Alternaria alternata (Fr.) Keissl. and the recently described fungus Diaporthe ilicicola $\mathrm{S}$. Lin, Taylor \& Peduto Hand, as well as other minor pathogens such as A. arborescens E. G. Simmons, Colletotrichum fioriniae (Marcelino \& Gouli) Pennycook, C. nymphaeae (Pass.) Aa, fungi in the D. eres Nitschke species complex, and Epicoccum nigrum Link (Lin et al. 2018). Seasonal symptoms of the disease include leaf spots that eventually lead to early plant defoliation (September rather than October), and dull, shriveled, undersized fruit that fails to turn color and eventually becomes rotten (Lin et al. 2018). On older plants, cankers and dieback can also occasionally be observed.

Cut branches of deciduous holly are traditionally used for winter holiday decorations, and the brightly colored fruit is the main interest for customers (Galle 1997). Due to the fruit turning necrotic, in the

${ }^{\dagger}$ Corresponding author: F. Peduto Hand; E-mail: hand.81@osu.edu

Funding: This study was funded by the Ohio Department of Agriculture Specialty Crop Promotion Program (awards AGR-SCG-14-08 and AGR-SCG16-09), the United States Department of Agriculture-National Institute of Food and Agriculture Hatch project number 1004939, the T. J. Kavanagh Foundation, and The Ohio State University Department of Plant Pathology.

The research described in this article represents a portion of the dissertation submitted by S. Lin to the Office of Graduate Studies of The Ohio State University to partially fulfill requirements for the Ph.D. degree in Plant Pathology. Its contents are solely the responsibility of the authors and do not necessarily represent the official views of the USDA.

*The $\boldsymbol{e}$-Xtra logo stands for "electronic extra" and indicates that one supplementary table is published online.

The author(s) declare no conflict of interest.

Accepted for publication 6 December 2018.

(c) 2019 The American Phytopathological Society last several years it was not economically feasible for growers to harvest the crop; therefore, diseased plant tissues were left in the field The presence of infected host tissues in the field has been identified as a source of inoculum for infection initiation and continuation throughout the growing season in many crop systems. For example, mummified fruit was identified as the main primary inoculum source for almond and olive anthracnose caused by Colletotrichum spp. (Förster and Adaskaveg 1999; Moral and Trapero 2012), and brown rot on stone fruit caused by Monilinia spp. Honey (Casals et al. 2015; Holb and Scherm 2007). Additionally, twigs, buds, or leaves could serve as sources of inoculum for apple leaf blotch and fruit spot disease caused by Alternaria spp. Nees (Harteveld et al. 2014; Tanaka et al. 1989), as well as Alternaria brown spot of mandarin (Bassimba et al. 2014) and Phomopsis cane and leaf spots of grape (Anco et al. 2012; Cucuzza and Sall 1982). Consequently, removal of infected plant tissues from fields has been suggested in different systems as a standard disease management practice to lower inoculum levels (Harteveld et al. 2014; Holb and Scherm 2007; Villarino et al. 2010).

Previous studies on the epidemiology of fruit rot of deciduous holly have identified developmental stages of the fruit susceptible to infections. Fruit infections caused by $D$. ilicicola occurred during the full-bloom or petal-fall stages, with the pathogen remaining quiescent until fruit maturation (Lin and Peduto Hand 2019). Also, wounded mature fruit was susceptible to infection by all pathogens tested (Lin and Peduto Hand 2019). However, inoculum availability in the field during these susceptible periods is currently unknown. Therefore, it is critical to monitor seasonal inoculum dynamics to formulate effective management strategies. Spore-trapping studies have been conducted to determine seasonal spore dynamics for avocado branch canker caused by fungal species in the Botryosphaeriaceae and Diaporthaceae families (Eskalen et al. 2013), as well as Alternaria brown spot of mandarin caused by A. alternata (Bassimba et al. 2014). The environmental factors, including rainfall and temperature, were reported to be influencing inoculum abundance, spore production, and infection in different climatic regions (Bassimba et al. 2014; Eskalen et al. 2013; Harteveld et al. 2014; Rotem 1994). The effects of these environmental factors on seasonal inoculum dynamics and on disease development in deciduous holly fields is currently unknown. 
Although important aspects of this fruit rot disease have been revealed, there is still lack of knowledge about many components of the disease cycle, including potential sources of pathogen inoculum and seasonal inoculum dynamics, as well as the effects of environmental factors on disease development and inoculum availability. Therefore, the objectives of this study were to (i) identify the plant tissues where pathogens causing fruit rot overwinter (i.e., primary inoculum), (ii) identify the potential source of secondary inoculum during plant development, (iii) determine the timing of spore dissemination during the growing season, and (iv) identify the effects of temperature and precipitation on leaf spot development and seasonal inoculum dynamics in the field.

\section{Materials and Methods}

Trial locations and characteristics. Field trials were initially established in two nurseries in Madison, $\mathrm{OH}$ (nurseries $\mathrm{A}$ and $\mathrm{B}$ ) in 2015 and 2016, which were exposed to natural pathogen inoculum and in which fruit rot had been observed yearly since 2014 (Lin et al. 2018). Due to low disease incidence $(<5 \%)$ observed at the end of the 2015 season, a third nursery (nursery C), located in Wooster, OH, in which fruit rot had also been recorded (Lin et al. 2018), was added in 2016. Trials were conducted in each nursery for two consecutive seasons (2015 and 2016 in nurseries A and B and 2016 and 2017 in nursery C). Plant material included two susceptible cultivars of the deciduous holly hybrid Ilex verticillata $\times I$. serrata $(22-$ and $24-$ year-old cultivar Bonfire in nurseries $\mathrm{A}$ and $\mathrm{C}$, respectively, and 27-year-old cultivar Sparkleberry in nursery B). At all locations, the experimental plot comprised 20 trees from one individual row within the production field. In nurseries A and B, the rows surrounding the trial plots served as buffer zones, and both trial plots and buffer zones were not disturbed by any management practice at any point of the growing season throughout the duration of the trial. The rest of the field was managed according to the grower's standard practices. In nursery $\mathrm{C}$, the entire nursery, including the experimental plot, was not disturbed by any management practice throughout the duration of the trial.

Assessment of sources of primary inoculum. One-year-old twigs and mummified fruit from the previous growing season were collected on 1 April of each year from each nursery (nurseries A and B in 2015; nurseries A, B, and C in 2016; and nursery C in 2017), except that no mummified fruit was available in nurseries $A$ and B in 2016 due to bird activity. During each sampling, six individual twigs with no visible cankers plus 10 mummified fruit were randomly collected from the entire canopy of each of the 20 trees in the experimental plots, then pooled together inside a plastic bag (one bag per type of tissue sampled per nursery). Bags containing the samples were transported to the laboratory inside a cooler and stored at $4{ }^{\circ} \mathrm{C}$ for a maximum of $24 \mathrm{~h}$ before further processing. In all, 60 overwintering twigs and 100 mummified fruit were then randomly extracted from the respective bags from each nursery and processed as described herein: overwintering twigs were surface disinfected for $5 \mathrm{~s}$ in $70 \%$ ethanol, followed by $1 \mathrm{~min}$ in $0.5 \%$ household bleach $(6 \%$ sodium hypochlorite; The Clorox Company, Oakland, CA), while mummified fruit were surface disinfected for $2 \mathrm{~min}$ in $2 \%$ household bleach ( $6 \%$ sodium hypochlorite; The Clorox Company); both types of samples were then rinsed in sterile water three times. All samples were allowed to air dry on sterile paper towels inside a laminar flow hood. Buds, bark, and xylem of each twig were separated using a sterile scalpel. Bark and xylem tissues were further cut into 2-by-5$\mathrm{mm}$ sections. One each of individual bud, bark, and xylem sections per twig were randomly selected and plated on potato dextrose agar (PDA; Difco Laboratories, Sparks, MD) amended with $0.1 \%$ lactic acid, $0.01 \%$ tetracycline hydrochloride, and $0.015 \%$ streptomycin sulfate (Fisher Scientific, Fair Lawn, NJ). Each mummified fruit was cut horizontally in half and plated cut-side down on V8 juice agar rather than PDA to facilitate recovery of some fungi with slower growth (Olatinwo et al. 2003). All plates were incubated on a laboratory bench under constant light at $25^{\circ} \mathrm{C}$ for up to 10 days. Fungal colonies developing from the tissues were counted and subcultured onto a new PDA plate. Pure cultures of each isolate, obtained by hyphal tip transfer, were preserved as mycelial plugs in sterile distilled water at $4{ }^{\circ} \mathrm{C}$ (Humber 1997). All isolates were tentatively identified to species based on morphology (Barnett and Hunter 1998; Baumgartner et al. 2013; Dissanayake et al. 2015; Lin et al. 2018; Mahadevakumar et al. 2014; Shivas and Tan 2009; Simmons 2007; Udayanga et al. 2014; Velho et al. 2015; Wu et al. 2017). For isolates exhibiting similar morphological characteristics, at least half of those recovered from each nursery and each type of plant tissue were subject to molecular characterization to confirm identity, as described by Lin et al. (2018).

Assessment of source of secondary inoculum. Holly leaves were sampled weekly or biweekly from bud break until plants were more than $30 \%$ defoliated to monitor leaf spot development and progression. Leaves were collected from 15 May to 29 October 2015 from nurseries A (total samplings, $n=12)$ and $\mathrm{B}(n=12)$; from 12 May to 29 October 2016 from nursery $\mathrm{A}(n=16)$ and $\mathrm{B}(n=16)$; and from 12 May to 6 October $2016(n=13)$ and 12 May to 29 September 2017 $(n=13)$ from nursery C. At each sampling time, 10 individual leaves were randomly collected from the entire tree canopy of each of the 20 trees in the experimental plots, pooled together, and mixed thoroughly inside a plastic bag. Then, 100 leaves were randomly extracted from the pool, and leaf spot incidence and severity were visually assessed on each leaf. Disease incidence was assessed as presence or absence of leaf spots, while disease severity was assessed as the percentage of leaf surface affected by leaf spots. Total leaf spot incidence and severity were then calculated for each nursery. Subsequently, symptomatic leaves were subject to fungal isolation as described herein; leaves were surface disinfected in $2 \%$ household bleach ( $6 \%$ sodium hypochlorite; The Clorox Company) for $30 \mathrm{~s}$, followed by $50 \%$ ethanol for $30 \mathrm{~s}$, and rinsed three times in sterile water. Leaves were then placed on sterile paper towels inside a laminar flow hood to air dry. Up to 30 pieces of leaf tissues ( 2 by $2 \mathrm{~mm}$ ) were cut from the edge of randomly selected lesions on each leaf, then transferred to amended PDA as previously described. Plate incubation, fungal isolation, identification, and preservation of the fungal isolates were the same as described above.

Pathogenicity tests. Two sets of experiments, each being conducted twice, were conducted to determine pathogenicity of the fungal isolates recovered from leaf spots on different plant tissues. One isolate of each of the major fungal species causing fruit rot (i.e., A. alternata, D. ilicicola, C. fioriniae, and E. nigrum) (Lin et al. 2018) recovered from each nursery and year (if applicable), was randomly selected and used in each experiment. In the first experiment (A), 1-month-old healthy leaves were collected from 3-year-old potted I. verticillata $\times$ I. serrata 'Sparkleberry' plants and immediately surface disinfected as previously described. Ten individual leaves were wounded on eight spots per leaf using a sterile needle; $6 \mu l$ of a sterile water-Tween 20 solution $(0.05 \%$ [ $\mathrm{vol} / \mathrm{vol}])$ containing each isolate at $10^{5}$ conidia/ml were then individually placed on each wound, as well as on eight spots on 10 unwounded leaves. In total, 10 wounded and 10 unwounded leaves inoculated with the same amount of sterile water-Tween 20 solution $(0.05 \%$ [ $\mathrm{vol} / \mathrm{vol}])$ served as controls. Leaves were arranged in a completely randomized design on a plastic tray enclosed in a clear polyethylene bag containing wet sterile paper towels. The tray was incubated on a laboratory bench under constant light at $25^{\circ} \mathrm{C}$ for up to 5 weeks. Leaf spot incidence was recorded as described above for each isolate. Fungal reisolation from leaf spots and morphological identification of the isolates were carried out to prove their pathogenicity.

In experiment $\mathrm{B}$, the same isolates used in experiment $\mathrm{A}$ were tested for pathogenicity on holly fruit. Healthy mature fruit was collected from the same plants used in experiment A and surface disinfected as described above. Eight individual fruit were used for each isolate. Each fruit was wounded using a sterile needle and point inoculated using a micropipette with $6 \mu$ l of a sterile water-Tween 20 solution $(0.05 \%$ [ $\mathrm{vol} / \mathrm{vol}])$ containing each isolate at $10^{5} \mathrm{conidia} / \mathrm{ml}$. Eight wounded fruit inoculated with $6 \mu \mathrm{l}$ of sterile water-Tween 20 solution $(0.05 \%$ [ $\mathrm{vol} / \mathrm{vol}])$ were used as controls. Experimental design, fruit incubation conditions, disease assessment, reisolation, and identification of the fungal isolates were the same as described above. 
Spore-trapping studies. Spore-trapping studies were carried out in nurseries A and B in 2015 and 2016 and in nursery C in 2016 and 2017. Spore traps consisted of glass microscope slides ( 25 by 75 by $1 \mathrm{~mm}$; Fisher Scientific) coated on both sides with a thin layer of petroleum jelly (TopCare, Elk Grove Village, IL), which were secured on holly branches using a clip binder and a zip tie (Fig. 1). Two spore traps were placed at approximately 70 and $140 \mathrm{~cm}$ aboveground, respectively, on the 5th, 11th, and 16th tree within the experimental plot of each nursery (i.e., every 5 or 6 trees). Spore traps were changed weekly from 1 April to 12 November 2015, 1 April to 28 November 2016, and 1 April to 22 November 2017 and collected individually in sterile 50-ml screw-cap tubes. Upon collection, spore traps were transported to the laboratory inside a cooler and stored at $4{ }^{\circ} \mathrm{C}$ for a maximum of $24 \mathrm{~h}$ before being processed. For each spore trap, a spore suspension was obtained by adding $10 \mathrm{ml}$ of sterile distilled water into the tube and shaking vigorously for $1 \mathrm{~min}$ by hand. Two 200- $\mu$ l suspension aliquots were placed on two replicateamended PDA plates as previously described, and spread using a sterile $90^{\circ}$ curved glass cell spreader (Chemglass Life Sciences LLC, Vineland, NJ). Plates were incubated on a laboratory bench at $25^{\circ} \mathrm{C}$ under constant light. Fungal CFU were counted for up to 3 weeks (Eskalen and Gubler 2001; Úrbez-Torres et al. 2010). Fungal isolate purification, identification, and preservation were the same as previously described.

Meteorological data. Meteorological data, including maximum, minimum, and average daily temperature as well as precipitation, were downloaded from the United States Department of AgricultureAgricultural Research Service weather research network (http:// www.oardc.ohio-state.edu/weather1/) available for Madison and Wooster, $\mathrm{OH}$ for the entire disease assessment periods (2015 to 2017).

Data analysis. To determine the sources of primary inoculum, the number of each overwintering plant tissue (i.e., bark, bud, xylem, and mummified fruit) that yielded fungal growth in each nursery each year was counted. Fungal isolation frequency was calculated for each type of plant tissue at each sampling location, as well as for pooled data across locations. To test the effects of type of plant tissue on fungal recovery, a $\chi^{2}$ goodness-of-fit test $(\alpha=0.05)$ was carried out for each individual pathogen on the pooled data using PROC FREQ in SAS (version 9.4; SAS Institute Inc., Cary, NC).

The area under the disease progress curve (AUDPC) was calculated independently for each nursery and year using leaf spot incidence and severity data collected throughout the growing season (Shaner and Finney 1977). Values of relative AUDPC (rAUDPC) were used to standardize the AUDPCs among nurseries and years, which were calculated using AUDPC values divided by the total number of days between the first (i.e., bud break) and the last assessment (Fry 1978). Due to intrinsic differences in trial locations and years of sampling, no statistical comparison was performed among rAUDPCs.

In the pathogenicity tests, leaf spot and fruit rot incidence data were subject to analysis of variance (ANOVA) using PROC GLM in SAS (version 9.4; SAS Institute Inc.). Datasets from the two experiment runs were combined prior to analysis when results were in congruence. All data were arcsine transformed before statistical analyses were performed and then back-transformed to present results. Tukey's honestly significant difference test $(\alpha=0.05)$ was used for mean comparisons among pathogens.

In the spore-trapping studies, the CFU per milliliter of spore suspension of each holly fruit rot pathogen (i.e., Alternaria, Colletotrichum, Diaporthe, and Epicoccum spp.) were calculated for each sampling location and time, as well as its corresponding area under the spore production curve (AUSPC) (Scherm et al. 2008). In order to determine seasonal spore abundance at different phenological stages of plant development in the field, values of AUSPC across the 2 years of data collection in each nursery were calculated for each of six plant developmental stages as indicated herein: stage 0 (leaf emergence), from the establishment of the trial with plants that are still in dormancy to the onset of flower bud development, April to June; stage 1 (flower bud), June; stage 2 (full bloom), June; stage
3 (petal fall), June; stage 4 (immature fruit), June to September; and stage 5 (mature fruit), September to December. To standardize AUSPC in each stage, relative AUSPC (rAUSPC) was calculated using values of AUSPC divided by the number of days in the corresponding stages (Fry 1978). A repeated-measures ANOVA was performed to compare rAUSPC of different stages of plant development (stages 0 to 5) for each individual pathogen. All data were arcsine transformed and analyzed using PROC GLIMMIX in SAS (version 9.4; SAS Institute Inc.), then back-transformed to present results. The number of days of each plant developmental stage was specified in the WEIGHT option. The stage of plant development and nursery were treated as fixed factors, while the year was treated as a random factor. Least-squares means $(\alpha=0.05)$ were used for comparison among factors.

Finally, to determine the relationship between leaf spot development or seasonal spore abundance and environmental variables, the mean maximum, minimum, and average daily temperature and accumulated precipitation between consecutive disease assessments from the period of 1 week before visible symptoms until the last disease assessment, or between consecutive spore traps collections, were calculated for each nursery and year during the entire experiment periods. Pearson's correlation test $(\alpha=0.05)$ was used to analyze the correlation between meteorological factors and leaf spot incidence and severity or spore counts using PROC CORR in SAS (version 9.4; SAS Institute Inc.).

\section{Results}

Primary inoculum. From 2015 to 2017, in total, 360 twigs as well as 400 mummified fruit from three nurseries were processed. Although no fungi were isolated from the twigs' xylem, species of Alternaria, Cladosporium Link, Colletotrichum, Diaporthe, Epicoccum, Fusarium Link, and Phoma Sacc. and fungi in the family Botryosphaeriaceae Theiss. \& P. Syd. were isolated from the bark, buds, or mummified fruit. Among these, the two most frequently isolated genera were Alternaria and Diaporthe from both bark and buds, and Alternaria and Epicoccum from mummified fruit (data not shown). Selected isolates recovered from bark $(n=9)$, buds $(n=$ $7)$, and mummified fruit $(n=13)$ were identified as A. alternata, A. arborescens, $C$. fioriniae, $C$. nymphaeae, $D$. ilicicola, fungi in the $D$. eres species complex, and E. nigrum, based on morphological features and molecular characterization, as described by Lin et al. (2018) (data not shown). All fungi were recovered from bark, buds, and mummified fruit, except for the genus Colletotrichum, which was not recovered from buds (Table 1). The highest isolation frequency of Alternaria, Colletotrichum, and Epicoccum spp. was obtained from mummified fruit, while that of Diaporthe spp. was obtained from bark (Table 1).

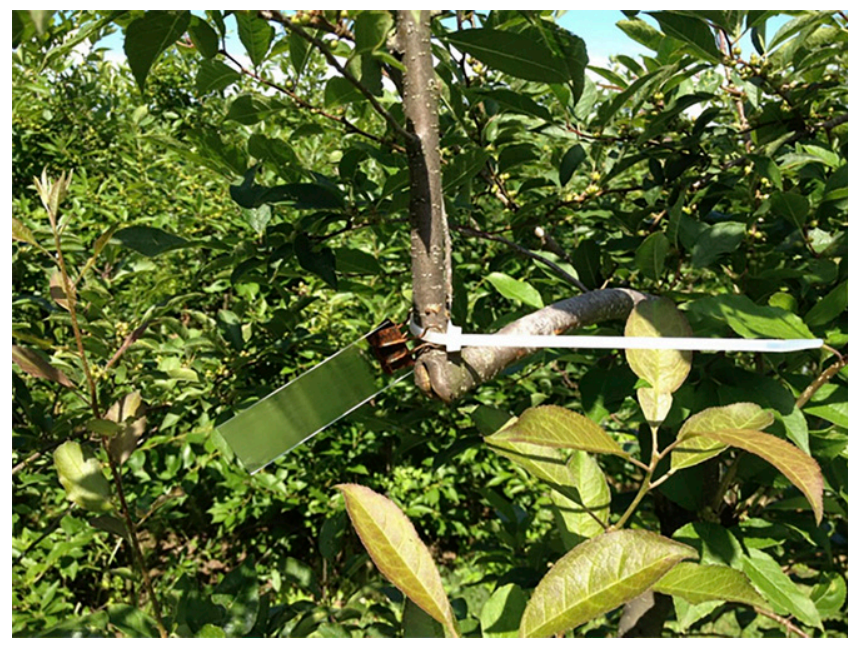

Fig. 1. Glass microscope slide coated with petroleum jelly used as a spore trap hanging from a deciduous holly tree. 
Secondary inoculum. Over the 3 years of sampling from the three nurseries, 938 of the 1,532 symptomatic leaves processed yielded fungal growth. Species of Alternaria and Diaporthe were the most frequently isolated pathogens from leaf spots (59.38 and $25.48 \%$, respectively), followed by Epicoccum, Colletotrichum, Phoma, fungi in the family Botryosphaeriaceae, and Pestalotia De Not. $(<10 \%)$ (Table 2). Of the 75 isolates that were selected for morphological and molecular identification, the most prevalent species were the same as those recovered from the overwintering plant tissues, including A. alternata, A. arborescens, C. fioriniae, C. nymphaeae, D. ilicicola, fungi in the $D$. eres species complex, and E. nigrum (data not shown).

Leaf spot symptoms were first observed on 26 June 2015 and 18 August 2016 in nursery A, 26 June 2015 and 25 August 2016 in nursery B, and 15 July 2016 and 7 July 2017 in nursery C. Leaf spots were initially light brown and irregularly shaped. As disease progressed over the season, lesions turned dark brown to black and coalesced, causing blighted areas (Fig. 2) and subsequent leaf drop. Leaf spot incidence and severity increased along with leaf and fruit development, and ranged from 70 to 100 and 10.79 to $33.37 \%$, respectively, by the final disease assessment (Table 3 ). For nurseries $\mathrm{A}$ and $\mathrm{C}$, incidence and severity rAUDPC values in the first sampling year (i.e., 2015 for nursery A and 2016 for nursery C) were lower than those in the second year (i.e., 2016 for nursery A and 2017 for nursery C) (Table 3). The opposite trend was observed in nursery $\mathrm{B}$.

Table 1. Fungal isolation frequency from overwintering plant tissues, including bark, bud, xylem, and mummified fruit collected from nurseries A, B, and C from 2015 to 2017

\begin{tabular}{|c|c|c|c|c|c|}
\hline \multirow[b]{2}{*}{ Pathogen } & \multirow[b]{2}{*}{$\begin{array}{l}\text { Overwintering } \\
\text { plant tissue }\end{array}$} & \multicolumn{4}{|c|}{ Isolation frequency $(\%)$} \\
\hline & & $\begin{array}{c}\text { Nursery } \\
A^{\mathbf{x}}\end{array}$ & $\underset{B^{\mathbf{x}}}{\text { Nursery }}$ & $\underset{C^{x}}{\text { Nursery }}$ & Pooled ${ }^{y}$ \\
\hline \multirow[t]{4}{*}{ Alternaria } & Bark & 12.50 & 13.33 & 5 & $10.28 \mathrm{~b}$ \\
\hline & Bud & 8.33 & 10 & 0.83 & $6.39 \mathrm{~b}$ \\
\hline & Xylem & 0 & 0 & 0 & $0 \mathrm{c}$ \\
\hline & Mummified fruit & $70^{\mathrm{z}}$ & $100^{\mathrm{z}}$ & 86.5 & $85.75 \mathrm{a}$ \\
\hline \multirow[t]{4}{*}{ Diaporthe } & Bark & 4.17 & 22.50 & 31.67 & $19.44 \mathrm{a}$ \\
\hline & Bud & 1.67 & 10 & 24.17 & $11.94 \mathrm{~b}$ \\
\hline & Xylem & 0 & 0 & 0 & $0 \mathrm{c}$ \\
\hline & Mummified fruit & $9^{\mathrm{z}}$ & $7^{\mathrm{z}}$ & 20 & $14 \mathrm{~b}$ \\
\hline \multirow[t]{4}{*}{ Colletotrichum } & Bark & 0 & 0 & 3.33 & $1.11 \mathrm{a}$ \\
\hline & Bud & 0 & 0 & 0 & $0 \mathrm{~b}$ \\
\hline & Xylem & 0 & 0 & 0 & $0 \mathrm{~b}$ \\
\hline & Mummified fruit & $0^{\mathrm{z}}$ & $0^{\mathrm{z}}$ & 2.5 & $1.25 \mathrm{a}$ \\
\hline \multirow[t]{4}{*}{ Epicoccum } & Bark & 18.33 & 2.5 & 3.33 & $8.06 \mathrm{~b}$ \\
\hline & Bud & 4.17 & 0 & 0.83 & $1.67 \mathrm{c}$ \\
\hline & Xylem & 0 & 0 & 0 & $0 \mathrm{~d}$ \\
\hline & Mummified fruit & $45^{\mathrm{z}}$ & $17^{\mathrm{z}}$ & 41.5 & $36.25 \mathrm{a}$ \\
\hline
\end{tabular}

${ }^{\mathrm{x}}$ Columns represent the value of pooled data across 2 years of observations in each nursery, unless otherwise noted.

${ }^{y}$ Column represents the value of pooled data across all years and nurseries. Values with the same letter within each pathogen are not significantly different according to $\chi^{2}$ goodness of fit test $(\alpha=0.05)$.

${ }^{z}$ Data include only 1 year of observations (mummified fruit was not present in 2016 due to bird activity).

Table 2. Fungal isolation frequency from the 938 symptomatic leaves that yielded fungal growth from 2015 to 2017 across all three nurseries

\begin{tabular}{lc}
\hline Fungal species & Isolation frequency $(\boldsymbol{\%})$ \\
\hline Alternaria spp. & 59.38 \\
Diaporthe spp. & 25.48 \\
Epicoccum spp. & 5.76 \\
Colletotrichum spp. & 5.12 \\
Phoma spp. & 3.62 \\
Botryosphaeriaceae spp. & 2.03 \\
Pestalotia spp. & 0.21 \\
\hline
\end{tabular}

No correlation was found between leaf spot incidence or severity and cumulative precipitation in any nursery-year combination (Table 4). Leaf spot incidence was negatively correlated to the mean average temperature in all observations, except for nurseries $\mathrm{A}$ and $\mathrm{B}$ in 2015 and nursery $C$ in 2017. Mean maximum and minimum temperatures were always negatively correlated to leaf spot incidence in nurseries $\mathrm{A}$ and $\mathrm{B}$ whereas, for nursery $\mathrm{C}$, only in the combined year $(2016+2017)$ observation (Table 4). Except for nurseries A and B in 2015 and nursery C in 2017, a negative correlation was found between leaf spot severity and mean maximum, minimum, and average temperatures (Table 4).

Pathogenicity tests. All isolates of A. alternata, C. fioriniae, D. ilicicola, and E. nigrum originally isolated from leaf lesions were able to infect detached wounded and unwounded holly leaves, which proved their pathogenicity (experiment A) (Supplementary Table S1). Leaf spot symptoms similar to those observed in the field started developing from the wounded treatments 1 week postinoculation. Unwounded treatments started developing symptoms 2 weeks postinoculation. Pycnidia formed on the lesions on leaves inoculated with D. ilicicola 3 weeks postinoculation. No symptoms were observed on the control leaves. All aforementioned isolates also successfully infected wounded mature fruit (experiment B) (Table 5). Fruit inoculated with A. alternata, C. fioriniae, and E. nigrum developed brown lesions from the wound, which enlarged to cover the entire fruit after 3 to 5 days, except for lesions caused by E. nigrum, which remained limited to the point of inoculation. Salmon discoloration of the fruit was observed on those inoculated with $D$. ilicicola 1 week postinoculation, followed by production of pycnidia on the entire fruit surface. Mean fruit rot incidence values reached $91.25 \%$ or above for all pathogens (Table 5). Fruit rot incidence caused by C. fioriniae was significantly lower than that of other inoculations (Table 5). No fruit rot developed on the control fruit.

Spore-trapping studies. Species of Alternaria, Cladosporium, Colletotrichum, Diaporthe, Epicoccum, Fusarium, and Phoma,

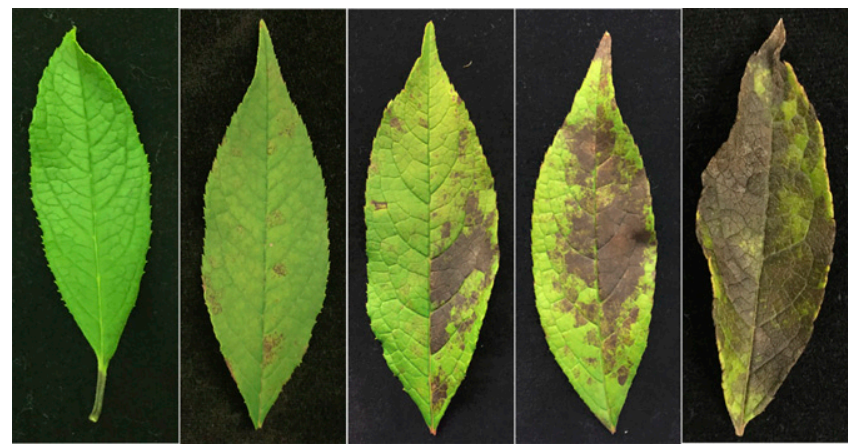

Fig. 2. Healthy leaf (left) and examples of different degrees of leaf spot severity observed on holly leaves.

Table 3. Measures of leaf spot incidence and severity used to compare disease development in nurseries A, B, and C from 2015 to 2017

\begin{tabular}{ccccccc}
\hline & & \multicolumn{2}{c}{$\begin{array}{c}\text { Mean final } \\
\text { assessment }(\%)^{\mathbf{y}}\end{array}$} & & \multicolumn{2}{c}{ rAUDPC $^{\mathbf{z}}$} \\
\cline { 3 - 4 } \cline { 6 - 7 } Year & Nursery & Incidence & Severity & & Incidence & Severity \\
\hline 2015 & $\mathrm{~A}$ & 70.00 & 10.79 & & 15.90 & 1.90 \\
& $\mathrm{~B}$ & 100.00 & 27.14 & & 32.80 & 5.80 \\
2016 & $\mathrm{~A}$ & 94.00 & 16.33 & & 28.30 & 2.80 \\
& $\mathrm{~B}$ & 100.00 & 33.37 & & 28.50 & 4.10 \\
& $\mathrm{C}$ & 92.00 & 21.67 & & 32.90 & 6.10 \\
2017 & $\mathrm{C}$ & 76.00 & 12.33 & & 40.10 & 7.60 \\
\hline
\end{tabular}

${ }^{y}$ Columns represent the mean disease value (\%) on the final assessment.

${ }^{\mathrm{z}}$ rAUDPC $=$ relative area under the disease progress curve. Columns represent the AUDPC values divided by the total number of days between the first (i.e., bud break) and the last assessment. Each nursery and year represent one data point. 
which were consistently isolated from the plant tissues processed in this study, were also retrieved from the spore traps. Spores were produced throughout the growing season. For Alternaria and Colletotrichum spp., the stage of plant development was a significant factor influencing spore abundance $(P=0.0044$, and 0.0272 , respectively); specifically, rAUSPC of Alternaria spp. at stage 2 (full bloom) was significantly higher than at stages 0 (leaf emergence), 1 (flower bud), 4 (immature fruit), and 5 (mature fruit); and rAUSPC of Colletotrichum spp. at stage 2 was significantly higher than at stages 0 and 5 (Table 6). For Diaporthe spp., nursery, stage of plant development, and their interaction were all significant factors $(P=0.0211$, 0.0477 , and 0.005 , respectively); specifically, rAUSPC at stage 2 in nursery $\mathrm{C}$ was significantly higher than in all other stage-nursery combinations (Table 6). No significant effect was found for Epicoccum spp.

A significant negative correlation was found between mean maximum, minimum, and average daily temperatures and number of Alternaria $(r=-0.18, P<0.05)$ and Epicoccum $(r=-0.18, P<$ 0.05 ) spores only, across 3 years of studies in all nurseries (data not shown). No correlation was found between spore counts and accumulated precipitation.

\section{Discussion}

In this study, we identified potential sources of primary and secondary inoculum of fruit rot pathogens of deciduous holly in Ohio nurseries. We also monitored seasonal inoculum dynamics and leaf spot progression, and described their relationship to environmental factors.

The pathogens causing fruit rot on deciduous holly were consistently isolated from the different overwintering host tissues analyzed, including buds, bark, and mummified fruit. Among these, mummified fruit was the main source of overwintering inoculum for Alternaria and Epicoccum spp., while mummified fruit and bark were equally important for Diaporthe spp. Genus Colletotrichum was also

Table 4. Correlation between leaf spot incidence and severity and environmental variables in nurseries A, B, and C from 2015 to 2017

\begin{tabular}{|c|c|c|c|c|c|}
\hline \multirow[b]{2}{*}{$\begin{array}{l}\text { Correlation } \\
\text { factor, nursery }\end{array}$} & \multirow[b]{2}{*}{ Year } & \multicolumn{4}{|c|}{$\begin{array}{l}\text { Pearson correlation } \\
\text { coefficient }(r)^{\mathrm{z}}\end{array}$} \\
\hline & & Precip & Max & Min & Avg \\
\hline \multicolumn{6}{|l|}{$\begin{array}{l}\text { Leaf spot } \\
\text { incidence }\end{array}$} \\
\hline \multirow[t]{2}{*}{ A } & 2015 & ns & $-0.64 *$ & $-0.74 *$ & ns \\
\hline & 2016 & $\mathrm{~ns}$ & $-0.87 * *$ & $-0.84 * *$ & $-0.82^{*}$ \\
\hline \multirow[t]{2}{*}{ B } & 2015 & ns & $-0.75^{*}$ & $-0.79 *$ & ns \\
\hline & 2016 & ns & $-0.89 * *$ & $-0.86^{*}$ & $-0.82 *$ \\
\hline \multirow[t]{2}{*}{$\mathrm{C}$} & 2016 & ns & $\mathrm{ns}$ & $\mathrm{ns}$ & -0.57 \\
\hline & 2017 & ns & ns & ns & ns \\
\hline A & $2015+2016$ & ns & $-0.51^{*}$ & $-0.62 *$ & $-0.57^{*}$ \\
\hline B & $2015+2016$ & $\mathrm{~ns}$ & $-0.73 * *$ & $-0.78 * *$ & -0.47 \\
\hline $\mathrm{C}$ & $2016+2017$ & ns & ns & -0.41 & $-0.49^{*}$ \\
\hline$A+B+C$ & $2015+2016+2017$ & ns & $-0.42 * *$ & $-0.58 * *$ & $-0.47 * *$ \\
\hline \multicolumn{6}{|l|}{$\begin{array}{r}\text { Leaf spot } \\
\text { severity }\end{array}$} \\
\hline \multirow[t]{2}{*}{ A } & 2015 & ns & $-0.81 *$ & $-0.87 * *$ & ns \\
\hline & 2016 & ns & $-0.96 * *$ & $-0.96 * *$ & $-0.91 * *$ \\
\hline \multirow[t]{2}{*}{ B } & 2015 & ns & $-0.9 * *$ & $-0.93 * *$ & ns \\
\hline & 2016 & ns & $-0.95 * *$ & $-0.93 * *$ & $-0.91 * *$ \\
\hline \multirow[t]{2}{*}{$\mathrm{C}$} & 2016 & ns & $-0.7 *$ & -0.63 & $-0.74 *$ \\
\hline & 2017 & ns & $\mathrm{ns}$ & -0.62 & -0.56 \\
\hline A & $2015+2016$ & ns & $-0.79 * *$ & $-0.87 * *$ & $-0.57^{*}$ \\
\hline B & $2015+2016$ & ns & $-0.9 * *$ & $-0.92 * *$ & -0.44 \\
\hline $\mathrm{C}$ & $2016+2017$ & $\mathrm{~ns}$ & $-0.54 * *$ & $-0.61 * *$ & $-0.67 * *$ \\
\hline$A+B+C$ & $2015+2016+2017$ & ns & $-0.53 * *$ & $-0.69 * *$ & $-0.45 * *$ \\
\hline
\end{tabular}

${ }^{\mathrm{z}}$ Precip $=$ accumulated precipitation $(\mathrm{mm})$, Max $=$ mean maximum temperature $\left({ }^{\circ} \mathrm{C}\right)$, Min $=$ mean minimum temperature $\left({ }^{\circ} \mathrm{C}\right)$, and $\mathrm{Avg}=$ mean average daily temperature $\left({ }^{\circ} \mathrm{C}\right)$. Symbols: $\mathrm{ns}=$ not significant $(P>0.05), *=$ significant at $P<0.01$, and $* *=$ significant at $P<0.001$. equally isolated from bark and mummified fruit, although at very low levels, but never retrieved from buds. Based on these findings, bark, buds, and mummified fruit should all be considered as potential sources of primary inoculum for these fruit rot pathogens.

Diaporthe spp. are common canker pathogens on many woody plants, including almond (Varjas et al. 2017), grape (Baumgartner et al. 2013), and pear (Bai et al. 2015). Although Diaporthe spp. are among the primary pathogens causing fruit rot of deciduous holly, cankers were rarely observed on the plants included in this study, which, at the time this disease was first found in 2012 (Lin et al. 2018), were 19 to 24 years old. This may be due to the fact that trees might be more susceptible to cankers as they grow older (Amponsah et al. 2017; Arnold and Straby 1973). Indeed, just recently (2017), a canker was observed on a twig in the experimental plot, from which D. ilicicola was isolated (data not shown). Additionally, cankers and dieback were observed in older fields on plants that were more than 40 years old (S. Lin, personal observation). Continuing to monitor canker development in nurseries will be important to identify if and when infected limbs should be pruned.

As suggested in other crop systems, infected host tissues should be removed from the field to decrease inoculum levels (Harteveld et al. 2014; Holb and Scherm 2007; Villarino et al. 2010). In deciduous holly commercial production, only one-quarter to one-third of the branches carrying the fruit are harvested from the plants to be sold (Galle 1997). In some years, branch harvest could be even lower due to decreased product demand or poor fruit quality, in which cases twigs and mummified fruit remain in the field until early spring. A previous study carried out to determine the effects of inoculum concentrations on holly fruit infection using detached fruit suggested that higher inoculum concentration could result in more severe disease (Lin et al. 2018). Therefore, removal of overwintering infected twigs and mummified fruit potentially harboring fruit rot pathogens should

Table 5. Results of the pathogenicity tests conducted on detached fruit using selected fungal isolates retrieved from symptomatic leaves collected in the three nurseries

\begin{tabular}{lccc}
\hline Fungal species & Isolate number & $\begin{array}{c}\text { Isolate } \\
\text { origin }^{\mathbf{y}}\end{array}$ & $\begin{array}{c}\text { Fruit rot } \\
\text { incidence }(\%)^{\mathbf{z}}\end{array}$ \\
\hline Alternaria alternata & FPH2015319 & $\mathrm{A}$ & 100.00 \\
& FPH2016506 & A & 100.00 \\
& FPH2015335 & B & 100.00 \\
& FPH2016534 & B & 100.00 \\
& FPH2016587 & C & 100.00 \\
Mean & FPH2017129 & C & 100.00 \\
Diaporthe ilicicola & $\ldots$ & $\ldots$ & $100.00 \mathrm{~A}$ \\
& FPH2015307 & A & 81.25 \\
& FPH2015314 & B & 93.75 \\
Mean & FPH2016464 & B & 100.00 \\
Epicoccum nigrum & FPH2016557 & C & 93.75 \\
& FPH2017127 & C & 100.00 \\
& $\ldots$ & $\ldots$ & $93.75 \mathrm{a}$ \\
& FPH2015327 & A & 100.00 \\
& FPH2016571 & A & 93.75 \\
Mean & FPH2015321 & B & 100.00 \\
Colletotrichum fioriniae & FPH2016576 & B & 100.00 \\
& FPH2016582 & C & 100.00 \\
& $\ldots$ & $\ldots$ & $98.75 \mathrm{a}$ \\
& FPH2015326 & A & 100.00 \\
Mean & FPH2015339 & B & 93.75 \\
& FPH2016410 & B & 81.25 \\
& FPH2016484 & C & 100.00 \\
& FPH2017157 & C & 81.25 \\
& $\ldots$ & $\ldots$ & $91.25 \mathrm{~b}$ \\
\hline
\end{tabular}

${ }^{x}$ The first four digits in the isolate number refer to the year of isolation.

${ }^{y}$ Nursery from which the isolate was retrieved.

${ }^{\mathrm{z}}$ Back-transformed value of pooled data from two experiment runs. Inoculations were done on wounded fruit only. Values with the same letter are not significantly different according to Tukey's honestly significant difference test $(\alpha=0.05)$. 
be recommended to decrease inoculum concentration in the field. Although complete mummified fruit removal is not practical for growers to implement due to the small fruit size and large number of fruit per plant, pruning infected twigs with attached diseased fruit could be feasible.

More than 3 years of leaf collection from three nurseries revealed that Alternaria and Diaporthe spp. were the pathogens most frequently associated with leaf spots ( $>25 \%)$, followed by Epicoccum and Colletotrichum spp. (>5\%). Additionally, the species A. alternata and D. ilicicola were consistently isolated from each sampling location and year. This was in agreement with the results of symptomatic fruit isolations carried out in previous studies (Lin et al. 2018), and reinforces our conclusions that A. alternata and D. ilicicola are the primary pathogens in the fungal complex, while $A$. arborescens, $C$. fioriniae, $C$. nymphaeae, fungi in the $D$. eres species complex, and E. nigrum are minor pathogens causing both leaf spots and fruit rot.

Leaf spot symptoms caused by the individual pathogen were not distinct and, in approximately one-third of the cases, fungi were not recovered from leaf lesions. Therefore, some leaf symptoms may have been caused by other factors such as insect activity, mechanical injury, herbicide drift, or extensive periods of leaf wetness (Galle 1997). Although, in the current study, we focused on the role leaf spots caused by fungal pathogens might have in the disease cycle, the effects of other factors causing leaf spots should be further investigated.

Sources of primary and secondary pathogen inoculum are known to be associated with the level of disease developing in fields (Harteveld et al. 2014; Holb and Scherm 2007; Villarino et al. 2010). Thus, differences in rAUDPC observed across nurseries in this study may have been due to the amount of inoculum present in each field. For example, in 2015, rAUDPC values in nursery A were lower than in nursery $\mathrm{B}$, which may have been due to a lower level of primary inoculum present in nursery A. Indeed, even though, in 2014, both nurseries experienced severe fruit rot and the nonmarketability of

Table 6. Results of the spore-trapping studies conducted in the three nurseries from 2015 to 2017

\begin{tabular}{lccccl}
\hline & & \multicolumn{4}{c}{ rAUSPC $^{\mathbf{w}}$} \\
\cline { 3 - 6 } Pathogen & Stage $^{\mathbf{x}}$ & Nursery A $^{\mathbf{y}}$ & Nursery B $^{\mathbf{y}}$ & Nursery $^{\mathbf{y}}$ & Pooled $^{\mathbf{z}}$ \\
\hline Alternaria & 0 & 0.24 & 0.03 & 0.33 & $0.20 \mathrm{a}$ \\
& 1 & 1.63 & 0.25 & 0.00 & $0.63 \mathrm{a}$ \\
& 2 & 3.32 & 3.27 & 6.00 & $4.20 \mathrm{~b}$ \\
& 3 & 0.25 & 1.69 & 0.82 & $0.92 \mathrm{ab}$ \\
Colletotrichum & 4 & 0.07 & 0.39 & 0.32 & $0.26 \mathrm{a}$ \\
& 5 & 0.07 & 0.71 & 0.10 & $0.29 \mathrm{a}$ \\
& 0 & 0.00 & 0.00 & 0.13 & $0.04 \mathrm{a}$ \\
& 1 & 0.00 & 0.00 & 0.44 & $0.15 \mathrm{ab}$ \\
Diaporthe & 2 & 1.25 & 5.00 & 2.00 & $2.75 \mathrm{~b}$ \\
& 3 & 0.00 & 0.71 & 4.36 & $1.69 \mathrm{ab}$ \\
& 4 & 0.34 & 0.21 & 0.07 & $0.21 \mathrm{ab}$ \\
& 5 & 0.00 & 0.11 & 0.12 & $0.08 \mathrm{a}$ \\
& 0 & 0.00 & 0.00 & 0.00 & $0.00 \mathrm{NA}$ \\
& 1 & 0.00 & 0.00 & 0.00 & $0.00 \mathrm{NA}$ \\
& 2 & 0.00 & 0.00 & 3.50 & $1.17 \mathrm{NA}$ \\
& 3 & 0.00 & 0.00 & 0.00 & $0.00 \mathrm{NA}$ \\
& 4 & 0.00 & 0.00 & 0.00 & $0.00 \mathrm{NA}$ \\
& 5 & 0.00 & 0.35 & 0.00 & $0.12 \mathrm{NA}$ \\
\hline
\end{tabular}

${ }^{\mathrm{w}}$ rAUSPC $=$ relative area under the spore production curve

$x$ Stage of plant development.

y Columns represent the value of pooled data across 2 years of observations in each nursery.

z Column represents the value of pooled data across all years and nurseries. Values with the same letter within each pathogen are not significantly different according to least-squares means $(\alpha=0.05)$. NA $=$ not applicable. rAUSPC values for Diaporthe were not compared across nurseries due to the significant interaction between nursery and stage of plant development $(P=0.005)$. The rAUSPC value at stage 2 in nursery $C$ is significantly higher than in all other nursery-stage combinations. the fruit led growers to not harvest any branches, at the beginning of 2015 , nursery A pruned infected twigs and removed some mummified fruit, a practice that could have been responsible for decreased inoculum concentrations. In 2016, rAUDPC in nurseries A and B were both lower than in nursery $\mathrm{C}$. One possible explanation could be that, although the trial plot and buffer zones in all nurseries were not disturbed by any management practice, the rest of nurseries $\mathrm{A}$ and $\mathrm{B}$ was subject to growers' standard practices, which, in the previous season (2015), included multiple chemical applications that resulted in little leaf spot observed outside of the trial plot (S. Lin, personal observation). This, in turn, could have been responsible for decreased inoculum levels in the entire field. In addition, low fruit rot incidence was observed in the entire field in nurseries A and B in $2015(<5 \%$; data not shown) and the fruit that was not harvested, which could have potentially served as a source of primary inoculum, was likely eaten by birds by the end of 2015. Moreover, the first leaf spot symptoms in nurseries A and B in 2015 were observed in June whereas, in 2016, they were observed in August. Delayed leaf spot development may have been the consequence of decreased field inoculum levels in 2016.

Similar considerations can be made regarding nursery $\mathrm{C}$, where rAUDPC in 2016 was lower than in 2017. Although no management practices were carried out in the entire nursery throughout the study period, branches were harvested at the end of 2015 (before the establishment of our trial) even though fruit rot was observed in the field. Therefore, some infected tissues potentially harboring pathogens were removed. Similar to what was observed for leaf spots, we previously reported that fruit rot incidence and severity in nursery $\mathrm{C}$ in 2016 was also lower compared with 2017 (Lin and Peduto Hand 2019). All of these observations reinforced the conclusion that removal of inoculum contributes to decreased infection during the growing season. That being said, although similar grower standard practices were carried out in nurseries A and B, rAUDPC of leaf spot incidence and severity in nursery A in 2015 was lower than in 2016 whereas, in nursery B, it was the opposite. This indicates that decreasing inoculum levels might not be the only factor influencing disease development.

Both leaf spot incidence and severity were found to be negatively correlated to mean maximum, minimum, and average daily temperature across sampling locations and years. This might suggest that low temperature could play a role in leaf spot development. However, a decrease in temperature coincided with leaf senescence, which may also be a factor influencing host susceptibility to infections (Häffner et al. 2015). Therefore, conclusions on the role of temperature on disease development cannot be made based on the data collected in this study.

All four major fruit rot causal agents (i.e., A. alternata, D. ilicicola, C. fioriniae, and E. nigrum) recovered from leaf spots were pathogenic to both wounded and unwounded young leaves but it took longer for unwounded leaves to develop symptoms, which suggested that any biotic or abiotic injury to the leaves should be avoided to minimize leaf infection. Furthermore, all of these leaf spot pathogens also successfully infected holly fruit in detached-fruit assays and produced the same symptoms observed in the field (Lin et al. 2018), which suggested the role of leaf spots as a source of secondary inoculum during the growing season. Consequently, any practices (e.g., chemical application or sanitation) that can reduce leaf spot occurrence might be helpful in reducing fruit infections.

The same group of fungal pathogens consistently isolated from host tissues was also recovered from the spore traps used in this study. Peak rAUSPC values of spore counts for Alternaria, Diaporthe, and Colletotrichum spp. across three nurseries mostly occurred during the full bloom stage. This supported the results of previous studies on the timing of fruit susceptibility to infection, in which the isolation frequency of Alternaria, Colletotrichum, and Epicoccum spp. from fruit exposed to natural inoculum increased after flowering, and where fruit artificially inoculated with $D$. ilicicola at the full bloom and petal fall stages successfully developed symptoms (Lin and Peduto Hand 2019). Spores of Diaporthe spp., among the primary pathogens in the disease complex, were mainly caught in nursery $\mathrm{C}$ but not frequently from nurseries $\mathrm{A}$ and $\mathrm{B}$. Even though the 
genus Diaporthe was identified as a main player in the disease based on extensive sampling across multiple years and locations (Lin et al. 2018), the relative distribution of this pathogen in a specific nursery could be different, which may explain the differences in inoculum abundance observed in this study across nurseries.

A correlation analysis was conducted to understand the role of environmental factors on spore production. Spore counts of Alternaria and Epicoccum spp. were negatively correlated to mean maximum, minimum, and average temperature; however, the Pearson correlation coefficient $(r)$ was very low $(-0.18)$. This could be due to the fact that only a few spores were caught by the spore traps across all locations and years of sampling, making it difficult to correlate with weather data. Spore traps made of glass slides coated with petroleum jelly (used in this study) have been successfully used to monitor seasonal spore abundance in vineyards and in mandarin and cherry orchards in Mediterranean-type climates (Bassimba et al. 2014; Eskalen and Gubler 2001; Trouillas et al. 2012; Úrbez-Torres et al. 2010) but their performance in colder climates was unknown. Although other spore-trapping devices are available for monitoring spore abundance (i.e., the Hirst-Burkard volumetric spore trap), they mostly rely on morphological identification of the spores directly from the traps or, alternatively, can be coupled with polymerase chain reaction-based assays using species-specific primers (Calderon et al. 2002). However, some pathogens of interest in this study (i.e., Alternaria, Diaporthe, and Epicoccum spp.) cannot be identified to species level solely using morphology (Lin et al. 2018). Also, because one of the primary pathogens in the fungal complex $(D$. ilicicola) was only recently described, no species-specific primers are currently available. The spore traps used in this study not only allowed us to obtain fungal colonies and further identify isolates to the species level using both morphological and molecular characterization but also were low cost, thus representing a useful exploratory tool to monitor inoculum dynamics in the field. The low spore numbers caught in this study were possibly due to the efficacy of the adhesive in capturing spores in our specific climatic conditions (Jenkyn 1974). Another possible reason for the low spore numbers caught could be that low levels of inoculum was available in the field during the period of the study due to the aforementioned removal of primary and secondary inocula. Indeed, nurseries A and B, which were regularly managed by growers, had relatively fewer spore counts compared with nursery $\mathrm{C}$, which was rarely disturbed. Even though the overall spore abundance was low, the above observations still support our conclusion that removal of primary and secondary inoculum would help to decrease field inoculum concentrations. Further studies to determine the effects of environmental factors on inoculum production should be carried out in nurseries with high levels of inoculum.

Based on our previous research (Lin and Peduto Hand 2019; Lin et al. 2018) and findings from the current study, we hypothesize that the disease cycle of fruit rot on deciduous holly is as follows. The disease causal agents overwinter in buds and bark of woody tissues, as well as mummified fruit left on the trees at the end of the growing season. Spores start to discharge from the primary inoculum sources after bud break. The majority of the spores are disseminated during flowering by means of wind or rain, or through the activity of pollinators. Open flowers as well as the developing fruit at petal fall and leaves are susceptible to primary infections. Pathogens such as $D$. ilicicola cause latent infections, remaining inactive in the developing fruit until as-yet-undetermined changes in host physiological properties occurring during fruit maturation activate them, resulting in rot symptom development from the stigma or calyx end of mature fruit. Leaves infected by primary inoculum develop leaf spot symptoms during summer. Conidia from the primary lesions infect other healthy leaves and establish secondary infections. Conidia produced on the infected leaves act as secondary inoculum to continue infecting newly emerged healthy leaves throughout the growing season as well as injured mature fruit at the end of the season. Expanded and coalesced leaf lesions result in early plant defoliation. Infected fruit is undersized and shriveled, loses gloss, and becomes rotten in November, just prior to harvest. Conidia produced from the infected fruit disseminate and infect other healthy fruit in the presence of open wounds.

This study contributed to deepen our understanding of this disease by identifying the sources of primary and secondary inoculum in nurseries and their dissemination throughout the growing season. The information generated through this study is of direct relevance to the design of disease management strategies. Experiments testing the efficacy of chemical treatments at different stages of fruit development are ongoing, and will likely result in improved management of this emerging disease.

\section{Acknowledgments}

We thank the holly growers in Ohio who provided many of the samples used in this study and G. Marchi for critical review of this manuscript prior to submission.

\section{Literature Cited}

Amponsah, N. T., Scheper, R. W. A., Fisher, B., Jesson, L. K., Walter, M., and Smits, J. M. 2017. The effect of wood age on infection by Neonectria ditissima through artificial wounds on different apple cultivars. N. Z. Plant Prot. 70:97-105.

Anco, D. J., Madden, L. V., and Ellis, M. A. 2012. Temporal patterns of sporulation potential of Phomopsis viticola on infected grape shoots, canes, and rachises. Plant Dis. 96:1297-1302.

Arnold, R. H., and Straby, A. E. 1973. Phomopsis elaeagni on Russian olive (Elaeagnus angustifolia) in Canada. Can. Plant Dis. Surv. 53:183-186.

Bai, Q., Zhai, L. F., Chen, X. R., Hong, N., Xu, W. X., and Wang, G. P. 2015 Biological and molecular characterization of five Phomopsis species associated with pear shoot canker in China. Plant Dis. 99:1704-1712.

Barnett, H. L., and Hunter, B. B. 1998. Illustrated Genera of Imperfect Fungi, 4th ed. American Phytopathological Society, St. Paul, MN.

Bassimba, D. D. M., Mira, J. L., and Vicent, A. 2014. Inoculum sources, infection periods, and effects of environmental factors on Alternaria brown spot of mandarin in Mediterranean climate conditions. Plant Dis. 98:409-417.

Baumgartner, K., Fujiyoshi, P. T., Travadon, R., Castlebury, L. A., Wilcox, W. F. and Rolshausen, P. E. 2013. Characterization of species of Diaporthe from wood cankers of grape in Eastern North American vineyards. Plant Dis. 97: 912-920.

Calderon, C., Ward, E., Freeman, J., and McCartney, A. 2002. Detection of airborne fungal spores sampled by rotating-arm and Hirst-type spore traps using polymerase chain reaction assays. J. Aerosol Sci. 33:283-296.

Casals, C., Segarra, J., De, C. A., Lamarca, N., and Usall, J. 2015. Overwintering of Monilinia spp. on mummified stone fruit. J. Phytopathol. 163:160-167.

Cucuzza, J. D., and Sall, M. A. 1982. Phomopsis cane and leaf spot disease of grapevine: Effects of chemical treatments on inoculum level, disease severity, and yield. Plant Dis. 66:794-797.

Dissanayake, A. J., Liu, M., Zhang, W., Chen, Z., Udayanga, D., Chukeatirote, E. Li, X. H., Yan, J. Y., and Hyde, K. D. 2015. Morphological and molecular characterization of Diaporthe species associated with grapevine trunk disease in China. Fungal Biol. 119:283-294.

Eskalen, A., Faber, B., and Bianchi, M. 2013. Spore trapping and pathogenicity of fungi in the Botryosphaeriaceae and Diaporthaceae associated with avocado branch canker in California. Plant Dis. 97:329-332

Eskalen, A., and Gubler, W. D. 2001. Association of spores of Phaeomoniella chlamydospora, Phaeoacremonium inflatipes, and Pm. aleophilum with grapevine cordons in California. Phytopathol. Mediterr. 40:429-432.

Förster, H., and Adaskaveg, J. E. 1999. Identification of subpopulations of Colletotrichum acutatum and epidemiology of almond anthracnose in California. Phytopathology 89:1056-1065.

Fry, W. E., 1978. Quantification of general resistance of potato cultivars and fungicide effects for integrated control of potato late blight. Phytopathology 68:1650-1655.

Galle, F. C. 1997. Hollies: The Genus Ilex. Timber Press, Portland, OR.

Häffner, E., Konietzki, S., and Diederichsen, E. 2015. Keeping control: The role of senescence and development in plant pathogenesis and defense. Plants 4: 449-488.

Harteveld, D. O. C., Akinsanmi, O. A., Chandra, K., and Drenth, A. 2014. Timing of infection and development of Alternaria diseases in the canopy of apple trees. Plant Dis. 98:401-408.

Holb, I. J., and Scherm, H. 2007. Temporal dynamics of brown rot in different apple management systems and importance of dropped fruit for disease development. Phytopathology 97:1104-1111.

Humber, R. A. 1997. Fungi: Preservation of cultures. Pages 269-279 in: Manual of Techniques in Insect Pathology. L. A. Lacey, ed. Academic Press, London.

Jenkyn, J. F. 1974. A comparison of seasonal changes in deposition of spores of Erysiphe graminis on different trapping surfaces. Ann. Appl. Biol. 76:257-267.

Lin, S., and Peduto Hand, F. 2019. Investigations on the timing of fruit infection by fungal pathogens causing fruit rot of deciduous holly. Plant Dis. 103:308-314.

Lin S., Taylor, N. J., and Peduto Hand, F. 2018. Identification and characterization of fungal pathogens causing fruit rot of deciduous holly. Plant Dis. 102 $2430-2445$ 
Mahadevakumar, S., Jayaramaiah, K. M., and Janardhana, G. R. 2014. First report of leaf spot disease caused by Epicoccum nigrum on Lablab purpureus in India. Plant Dis. 98: 284.

Moral, J., and Trapero, A. 2012. Mummified fruit as a source of inoculum and disease dynamics of olive anthracnose caused by Colletotrichum spp. Phytopathology 102:982-989.

Olatinwo, R. O., Hanson, E. J., and Schilder, A. M. C. 2003. A first assessment of the cranberry fruit rot complex in Michigan. Plant Dis. 87:550-556.

Rotem, J. 1994. The Genus Alternaria: Biology, Epidemiology and Pathogenicity. American Phytopathological Society, St. Paul, MN.

Scherm, H., Savelle, A. T., Boozer, R. T., and Foshee, W. G. 2008. Seasonal dynamics of conidial production potential of Fusicladium carpophilum on twig lesions in southeastern peach orchards. Plant Dis. 92:47-50.

Shaner, G., and Finney, R. 1977. The effect of nitrogen fertilization on expression of slow-mildewing resistance in Knox wheat. Phytopathology 67:1051-1056.

Shivas, R. G., and Tan, Y. P. 2009. A taxonomic re-assessment of Colletotrichum acutatum, introducing $C$. fioriniae comb. et stat. nov. and $C$. simmondsii $\mathrm{sp}$. nov. Fungal Divers. 39:111-122.

Simmons, E. G. 2007. Alternaria: An Identification Manual. CBS Fungal Biodiversity Centre, Utrecht, The Netherlands.

Tanaka, S., Shimomura, S., Takashima, E., Karumoro, K., and Nishi, Y. 1989. Occurrence of fungicide-resistant strains of Alternaria mali in Tokusa AtoChi Yamaguchi Prefecture Japan. Bull. Fac. Agric. Yamaguchi Univ. 37:49-60.
Trouillas, F., Peduto, F., Lorber, J., Sosnowski, M., Grant, J., Coates, W., Anderson, K., Caprile, J., and Gubler, W. D. 2012. Calosphaeria canker of sweet cherry caused by Calosphaeria pulchella in California and South Australia. Plant Dis. 96:648-658.

Udayanga, D., Castlebury, L. A., Rossman, A. Y., Chukeatirote, E., and Hyde, K D. 2014. Insights into the genus Diaporthe: Phylogenetic species delimitation in the D. eres species complex. Fungal Divers. 67:203-229.

Úrbez-Torres, J. R., Battany, M., Bettiga, L. J., Gispert, C., McGourty, G., Roncoroni, J., Smith, R. J., and Gubler, W. D. 2010. Botryosphaeriaceae species spore-trapping studies in California vineyards. Plant Dis. 94: 717-724.

Varjas, V., Vajna, L., Izsepi, F., Nagy, G., and Pajtli, E. 2017. First report of Phomopsis amygdali causing twig canker on almond in Hungary. Plant Dis. 101:1674.

Velho, A., Alaniz, S., Casanova, L., Mondino, P., and Stadnik, M. 2015. New insight into the characterization of Colletotrichum species associated with apple diseases in southern Brazil and Uruguay. Fungal Biol. 119:229-244.

Villarino, M., Melgarejo, P., Usall, J., Segarra, J., and De Cal, A. 2010. Primary inoculum sources of Monilinia spp. in Spanish peach orchards and their relative importance in brown rot. Plant Dis. 94:1048-1054.

Wu, D., Zhang, D. H., Timko, M. P., Li, M. Y., and Liang, G. L. 2017. First report of Epicoccum nigrum causing brown leaf spot of loquat in Southwestern China. Plant Dis. 101:1553. 